\title{
Utilization of the Mangrove Forest for Sustainable Renewable Energy Production
}

ISSN: 2637-8035

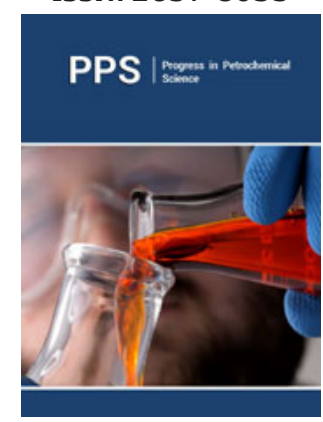

*Corresponding author: Aroloye 0 Numbere, Department of Animal and Environmental Biology, Nigeria

Submission: 監April 09, 2020

Published: 此 May 06, 2020

Volume 3 - Issue 3

How to cite this article: Aroloye 0 Numbere. Utilization of the Mangrove Forest for Sustainable Renewable Energy Production. Progress Petrochem Sci. 3(3). PPS.000561.2020.

DOI: $10.31031 /$ PPS.2020.03.000561

Copyright@ Aroloye 0 Numbere, This article is distributed under the terms of the Creative Commons Attribution 4.0 International License, which permits unrestricted use and redistribution provided that the original author and source are credited.

\author{
Aroloye 0 Numbere* \\ Department of Animal and Environmental Biology, Nigeria
}

\begin{abstract}
The tropics are generally evergreen and have large tree populations that make up the bulk of plant biomass. The Niger Delta is rich in biodiversity and has the largest mangrove system in Africa and the Atlantic. Above ground biomass (ABG) is a good indicator of stand productivity in mangroves, and can be calculated with allometric method using tree structural characteristics of dbh and tree height. Red mangroves are the most dominant species, and the species mostly used for making firewood and charcoal. The carbon stock estimates was higher in locations with more red mangrove trees $(66.1 \pm$ 15.1 $\left.\mathrm{Mgha}^{-1}\right)$ than locations with fewer red mangrove trees $\left(36.0 \pm 12.8 \mathrm{Mgha}^{-1}\right)$, which indicates that they are excellent carbon sequesters. Mangrove forest therefore supplies low cost renewable energy and also reduces global warming through carbon sequestration. Already, utilization of firewood and charcoal for cooking is a booming business in many communities in the Niger Delta. But the issue is that deriving sustainable energy from mangrove forest requires modern technology. Energy production from mangrove raw material will reduce the burden of energy generation from petroleum. This will thus, save the environment from pollution from oil and gas exploration which has led to ozone layer depletion. Nonetheless, mangrove-derived biomass energy will thus save the environment from sulphur and radioactive contamination.
\end{abstract}

Keywords: Goniopsis pelii; Rhizophora; Heavy metals; Bioaccumulation; Niger Delta; Hydrocarbons; Biomass; Calories; Carbon; Charcoal; Energy; Firewood; Mangrove; Rhizophora; Energy; Pollution

\section{Introduction}

Mangrove forest are found in the interface between the land and the sea where most negative impact of nature and humans are being felt the most because of the actions of hurricanes, and tsunamis [1], and crude oil spillages [2]. Mangroves are at the frontlines of the battle to recapture the environment from the jaws of anthropogenic devastation. They are naturally found in laborious terrain where they face onslaught from high velocity hurricanes, which break their branches and fall their stems. They are also battered by tidal surge from cyclone which sweeps through the entire forests and levels the trees [3].

Despite this natural attack by hazardous environmental phenomenon they still stand their ground defiantly and remain resilient [4]. This resilience can be attributed to their tough and flexible stems, which makes them elastic to pressures. Their stems have high recoiling ability to tidal pressure and keep them standing after hurricanes and tsunami had come and gone [5]. Mangroves forest therefore, absorbs and disorganizes high velocity winds and tidal surge, which is capable of wiping out a whole generation of plant community. Although, bad for the trees, this action protects human community from utter destruction. The stems don't only serve as wind and water breaks but also serve as biomass energy for producing renewable energy through firewood and charcoal manufacture for cooking in rural communities. Wood from trees and other plant material make up the traditional sources of biomass energy in rural areas [6].

Biomass is solar energy stored in organic matter via photosynthetic process where energy from the sun reacts with carbon dioxide to form food material. Biomass can produce solid fuel, liquid fuel, gas and electricity [7], but out of these forms of energy the solid fuel (i.e. fire wood and charcoal) are the most utilized in Africa and other third world countries. This is because 
these countries most often lack the needed technology to convert biomass to liquid, gaseous or electrical energy. Globally, biomass is the fourth source of energy, but in Nigeria it is the second source of energy after petroleum [8,9]. Nigeria is the highest producer of crude oil and has the largest mangrove vegetation in Africa [2]. Therefore, the energy potentials of biomass in Africa and other developing countries of the world are great if it can be efficiently utilized. For instance, $96 \%$ of rural dwellers in Tanzania [10] and $90 \%$ of rural dwellers in Nigeria utilize firewood and charcoal for cooking and heating.

Solid biomass fuel typically includes:

1. Firewood, charcoal and wood pellet,

2. Crop residue,

3. Animal waste,

4. Urban or municipal waste and
5. Fuel trees (plants cultivated mainly for their energy value). Utilizing firewood and charcoal is the highest bio-energy potential in Nigeria $(805,580 \mathrm{GJ})$ followed by animal $(47,718$ GJ) and agricultural $(325,822$ GJ) residues [11]. Majority of the firewood and charcoal utilized in Nigeria is derived from the stems and branches of the red mangrove trees (Rhizophora $s p p$ ). Epileptic electrical power supply has made large number of people in cities to utilize firewood as the second option for cooking and heating. Increased use of firewood has its environmental implications, which include land degradation and deforestation, which can cause other unexpected effects such as increased soil erosion and flooding. Unregulated removal of trees can also result to barren lands, which eventually becomes wastelands. Continuous felling of trees can also result in the loss of other ecosystem services provided by mangroves globally (Figure 1) and in the Niger Delta in particular $[12,13]$.

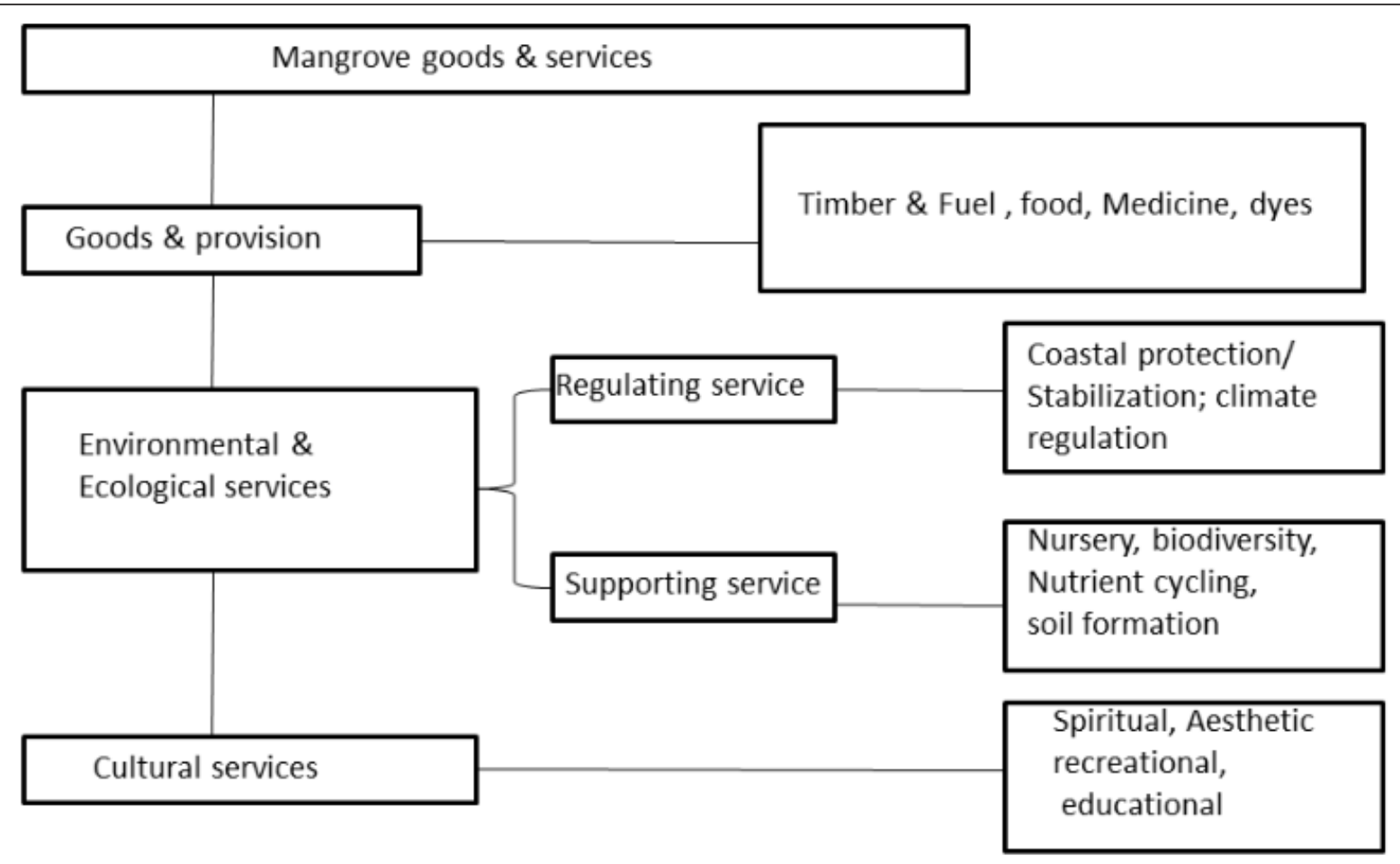

Figure 1: Ecosystem services of mangroves forest. Timber and fuel are produced from mangrove stem and branches. (Source: [13].

\section{Solid Biomass Energy from Mangroves}

There are over 150 species of mangroves globally, but the most dominant species in most parts of the world are the red mangroves (Rhizophora spp). In the Niger Delta there are three major species: the red (Rhyzophora racemosa), white (Avicennia germinans) and black (Laguncularia racemosa) mangroves and their percentage occurrence are $62.5 \%, 25 \%$ and $12.5 \%$ respectively [14,15]. All these three species are used to produce fire wood, but the most commonly used is the red mangrove because it has the highest potential (Table
1). This is followed by Sonneratia species. Rhizophora species is the best source of biomass energy because the stems are resilient and can catch fire and burn faster than stems of other species. They are thus used in producing firewood and charcoal, which are used for cooking, barbecue, heating of homes, drying of fish, baking, brick making, earthen pot making, casting of metal and ceramics. Red mangroves are used to produce firewood and charcoal. Similarly, Bruguiera, Ceriops, Conocarpus, Heritiera and Laguncularia can also be used to produce firewood and charcoal. 
Table 1: Potential of using different mangrove species to produce firewood and charcoal.

\begin{tabular}{|c|c|c|}
\hline Mangrove Species & Uses & Potential \\
\hline Aegiceras & Firewood & Good \\
\hline Avicennia & Firewood & Good \\
\hline Bruguiera & Firewood, charcoal & Good \\
\hline Camptostemon & Firewood & Good \\
\hline Ceriops & Firewood, charcoal & Good \\
\hline Conocarpus & Firewood, charcoal & Good \\
\hline Heritiera & Firewood, charcoal & Good \\
\hline Cynometra & Firewood & Good \\
\hline Kandelia & Firewood & Good \\
\hline Laguncularia & Firewood, charcoal & Good \\
\hline Lumnitzera & Firewood & Good \\
\hline Rhizophora* & Firewood, charcoal & Best \\
\hline Scyphiphora & Firewood & Good \\
\hline Sonneratia & Firewood & Very Good \\
\hline Xylocarpus & Firewood & Good \\
\hline
\end{tabular}

Source: [15].

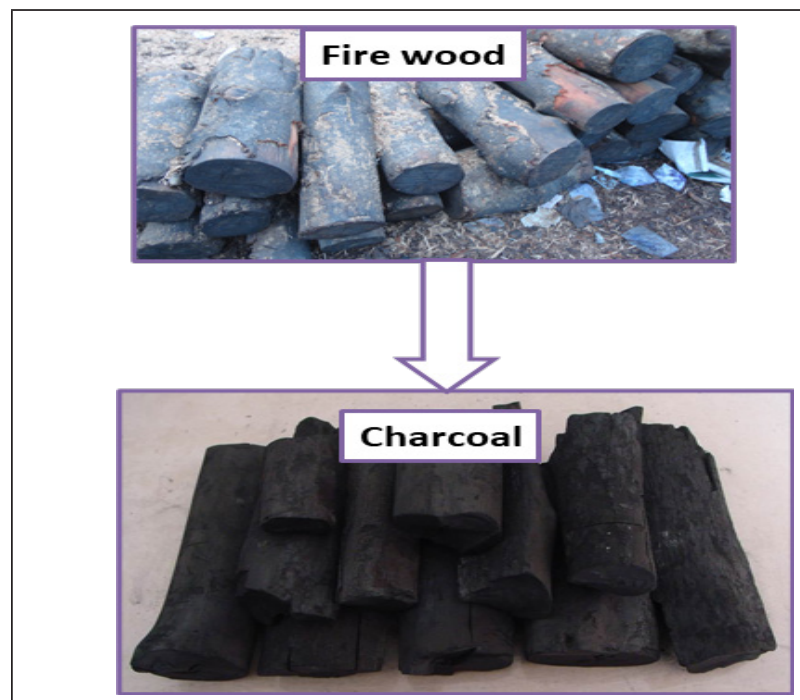

Figure 2: Conversion of red mangrove stem (Rhizophora spp) to charcoal log, which is further broken into smaller pieces for local cooking and roasting [17].

The stems of red mangroves come in different sizes, which are later chopped into pieces and sold for domestic and industrial use (Figure 2). For example, [16] reported an average of $106 \mathrm{~m}$ for of market size of firewood in the Niger Delta. Smaller pieces of mangroves stem are used for domestic cooking and heating of homes whereas bigger logs are used in industries such as in bakeries and smelting plants where furnaces are fed with big logs of firewood to generate high temperature for baking and casting respectively $[17,18]$. The mature red mangrove stem is bulky and dense and can grow up to $20-30 \mathrm{~cm}$ in diameter, which is an ideal range for fire wood and charcoal production (Table 2). Red mangroves (Rhizophora) are the heaviest in density followed by Acacia and birch. The later species are common in the temperate regions, while mangrove species are more prominent in tropical regions where high temperature and precipitation influence their growth and survival.

Table 2: Wood densities of different species of trees.

\begin{tabular}{|c|c|c|}
\hline Wood Type & Density $\left(\mathbf{K g} / \mathbf{m}^{3}\right)$ & Species \\
\hline Very hard wood & $>800$ & $\begin{array}{c}\text { Mangrove } \\
\text { (Rhizophora })\end{array}$ \\
\hline Heavy wood & $710-800$ & Acacia, beech \\
\hline Moderately heavy wood & $610-700$ & Birch, black cherry \\
\hline Moderately light wood & $510-600$ & Alder, chestnut \\
\hline Light wood & $410-500$ & Pine, spruce, fir \\
\hline Very light wood & $<400$ & Willow, gray alder \\
\hline
\end{tabular}

Source: Modified from [18].

The red mangrove is divided into sub-species, which include $R$. racemosa, $R$. mangle, $R$. harrisoni, and $R$. apiculata. Out of these four species $R$. apiculata is the best for fire wood and charcoal production [19]. In addition, the red mangrove stems stand out from other mangrove species because they have high calorific value ( $\sim 5$ calorie per gram), which is a significant factor in combustion (Table 3).

Table 3: Calorific value of different types of fuels.

\begin{tabular}{|c|c|c|}
\hline Fuel & Calorific Value MJ/Kg & Rank \\
\hline Air-dry wood & 15.5 & $6^{\text {th }}$ \\
\hline Completely dry wood & 18.5 & $5^{\text {th }}$ \\
\hline Brown coals & 19.5 & $4^{\text {th }}$ \\
\hline Hard coals & 28.5 & $3^{\text {rd }}$ \\
\hline Charcoal $^{*}$ & 29 & $2^{\text {nd }}$ \\
\hline Petroleum $^{\text {st }}$ & 42 & $1^{\text {st }}$ \\
\hline
\end{tabular}

Source: Modified from [18].

Consequently, red mangroves have high biomass energy and density, which makes them to last longer when burnt. Their ability to burn for a long time is what has made them the most favorite wood for cooking in both rural and urban areas, because they can be re-used several times without quickly decomposing into ash and carbon. Other wood species burn faster and within a short time become ash when placed in fire; the red mangrove stems burn to produce charcoal, which is another form of energy for cooking and heating. The bark of red mangroves is highly combustible and complements and enhances the burning ability of the inner wood. A unique aspect of red mangrove stem observed during field work is their ability to sustain burning when freshly cut and when still wet (Table 4), unlike other tree species that need to be dried first before they are used for cooking or heating. According to [19] Rhizophora had high calorific value for leaves and wood when heated at 200-250 ${ }^{\circ} \mathrm{C}$, and thus high percent charcoal formation with the 
exception of Sonneratia alba (Table 4). Although, red mangroves can be used when wet, their drying don't take too long, because the water within the wood evaporates and get dried fast. The dried salt within the mangrove wood accelerates burning. Mangrove stem has tightly packed inner wood grain, called cleaveness, which further improves the burning ability of the wood.

Table 4: Calorific value, percent moisture and charcoal productions in different mangrove species.

\begin{tabular}{|c|c|c|c|c|}
\hline \multirow{2}{*}{ Mangrove Species } & \multicolumn{2}{|c|}{ Calorific Value Cal/g } & \multirow{2}{*}{ Moisture (\%) } & \multirow{2}{*}{ Charcoal* $^{*}(\%)$} \\
\hline & Leaves & Wood & & \\
\hline Avicennia officinalis & 3668.69 & 5922.122 & 41.45 & 44.55 \\
\hline Avicennia marina var. acutissima & 3396.64 & 4901.053 & 60.59 & 51.76 \\
\hline Avicennia marina var. resinifera & 3347.15 & 5309.47 & 74.36 & 40.74 \\
\hline Avicennia Sps & 3108.18 & 2042.10 & 78.79 & 37.32 \\
\hline Rhizophora mucronata & 2256.00 & 6739.95 & 66.36 & 51.95 \\
\hline Rhizophora apiculata & 1436.00 & 5105.26 & 66.97 & 53.04 \\
\hline Sonneratia alba & 1182.00 & 4062.28 & 80.49 & 54.48 \\
\hline
\end{tabular}

Source: [19].

\section{Fire Wood is a Cleaner form Of Energy Production}

Mangrove forests are renewable resource, which means they have a turnover period of 15 years in attaining maturity after they are planted as compared to crude oil from which petroleum is manufactured, which takes thousands and millions of years to form within the earth crust. Even though petroleum has the highest calorific value, and widely utilized round the world (Table 3 ), the problem it creates for the world's environment, may last for generations, and would eventually undo its usefulness in the long run due to emerging climate change problems caused by pollution from release of exhaust. Biomass generally produces less carbon dioxide (CO2) and sulphur dioxide (SO2) pollutants as compared to petroleum. The burning of firewood emits less carbon into the atmosphere as compared to petroleum products, which has flooded the earth's atmosphere with green house gases (methane, water vapor, carbon dioxide, nitrous oxide, ozone etc). This has resulted to biodiversity losses and species extinctions in many parts of the world. In the Niger Delta many species had gone extinct; a classical example is the local extinction of some species within the lepidopteran (butterfly) family that were in large population over 30 years ago as a result of oil and gas exploration.

Nevertheless, the role of mangrove forest as carbons sequester $[20,21]$ had counteracted the adverse impact of firewood burning. This is because mangrove forest helps to filter the atmosphere of carbon dioxide, which is a major cause of global warming. Mangroves forests in tropical regions play critical role in purifying the environment, and if not for the mangroves, the impact in the air space and coastal territory of Africa would have been great. For instance, Nigeria and Angola are the two notable African countries who are the highest producers of crude oil. They are involved in oil and gas exploration and exploitation which lead to the emission of gaseous and liquid pollutants into the environment. All aspect of mangrove forest serves as carbon sink, right from the forest soil to the mangrove root, stem, branches and leaves. Therefore mangrove energy production is less injurious to the global environment, which is compensated by their ability to sequester carbon and filter the air. The utilization of firewood and charcoal as sources of energy is therefore a little prize to pay as compared to other forms of energy. After all, the worst polluters of the global environment are industrialized countries in Asia and the West [22] and not Africa.

\section{Carbon Stock Estimation of Red Mangrove Stems}

To derive the above ground biomass firstly, the diameter at breast height ( $\mathrm{dbh}$ ) and the height of the trees are measured with a measuring tape using allometric method (Table 4). This study was carried out in two locations (i.e. Okrika and Buguma) in the Niger Delta, Nigeria by [23]. Secondly, to derive the estimate of carbon stock half of the above ground biomass (AGB) was calculated (Table $5)$. The above ground biomass was calculated using the diameter at breast height by applying the formula of [24]. This equation is the Model 1 (diameter-height-wood density) mangrove biomass regression model (Eq. 1).

Table 5: Allometric calculations of tree stems in the Niger Delta, Nigeria.

\begin{tabular}{|c|c|c|c|c|}
\hline Location & No. of Stems Counted & Dominant spp. & Mean dbh (SE) (cm) & Mean Stand Height (SE) (m) \\
\hline Okrika & 255 & R. racemosa & $3.55 \pm 0.15$ & $2.33 \pm 0.09$ \\
\hline Okrika & 110 & R. mangle & $3.93 \pm 0.23$ & $2.48 \pm 0.13$ \\
\hline Okrika & 5 & A.germinans & $9.42 \pm 4.12$ & $3.17 \pm 0.78$ \\
\hline Okrika & 130 & R. racemosa & $5.02 \pm 0.25$ & $3.30 \pm 0.42$ \\
\hline
\end{tabular}




\begin{tabular}{|c|c|c|c|c|}
\hline Okrika & 50 & R. mangle & $4.79 \pm 0.46$ & $3.06 \pm 0.21$ \\
\hline Okrika & 40 & R. harrisonii & $4.36 \pm 0.40$ & $3.18 \pm 0.23$ \\
\hline Buguma & 151 & R. racemosa & $4.51 \pm 0.35$ & $3.04 \pm 0.11$ \\
\hline Buguma & 11 & R. mangle & $3.16 \pm 1.12$ & $2.52 \pm 0.34$ \\
\hline Buguma & 14 & A. germinans & $4.48 \pm 1.16$ & $3.17 \pm 0.35$ \\
\hline Buguma & 3 & L. racemosa & $4.68 \pm 1.45$ & $3.76 \pm 0.44$ \\
\hline Buguma & 202 & R. racemosa & $3.94 \pm 0.16$ & $2.60 \pm 0.09$ \\
\hline Buguma & 98 & A. germinans & $4.23 \pm 0.24$ & $2.31 \pm 0.11$ \\
\hline Buguma & 20 & L. racemosa & $3.51 \pm 0.49$ & $2.01 \pm 0.21$ \\
\hline
\end{tabular}

Source: [23].

Plot above ground biomass

$$
\left(A G B, M g h a^{-1}\right)=\sum_{i=1}^{N} a g b i \times 25(400) \text { Eq. } 1
$$

Where,

$$
a g b_{i}(k g)=0.0509 \times \rho \times d b h^{2} \times \text { treeheight Eq. } 2
$$

Where, $\rho$ is the wood specific gravity $\left(\mathrm{gcm}^{-3}\right)$. The wood specific density for R. racemosa $\left(0.96 \mathrm{gcm}^{-3}\right)$ and R. mangle (0.98) for African mangroves is derived from the Global Density Database [25-27].
The result revealed that the carbon stock estimates were higher in areas with more red mangroves species (Table 6). The range of carbon stock is between $23.18-81.16 \mathrm{Mgha}^{-1}$. Okrika location that has more red mangrove forest has higher carbon stock (66.1 \pm 15.1 $\mathrm{Mgha}^{-1}$ ) than Buguma that has fewer mangrove forests (Mgha1) (Table 6). These results are higher than that of Sofala Bay Central Mozambique (33.1 $\mathrm{Mgha}^{-1}$.) as reported by [28]. This exemplifies the fact that the mangroves of the Niger Delta contribute highly towards global carbon sequestration and the stabilization of the world's climate if protected and preserved for future generation.

\begin{tabular}{|c|c|c|c|c|c|c|}
\hline Location & Mangrove Species & Common Name & agbi (Kg) & AGB (Mg ha-1) & Carbon stock (Mg ha-1) & $\begin{array}{c}\text { Mean Carbon Stock/location } \\
\text { (SE) }\end{array}$ \\
\hline Okrika & R. racemosa & Red & 1.4348 & \multirow{3}{*}{162.32} & \multirow{3}{*}{81.16} & \\
\hline Okrika & R. mangle & Red & 1.9106 & & & \\
\hline Okrika & A. germinans & black & 12.8861 & & & \\
\hline Okrika & R. racemosa & Red & 4.0636 & \multirow{3}{*}{102.12} & \multirow{3}{*}{51.06} & \multirow{3}{*}{$66.1 \pm 15.1$} \\
\hline Okrika & R. mangle & Red & 3.5022 & & & \\
\hline Okrika & R. harrisonii & Red & 2.6462 & & & \\
\hline Buguma & R. racemosa & Red & 3.0215 & \multirow{4}{*}{97.48} & \multirow{4}{*}{48.74} & \\
\hline Buguma & R. mangle & Red & 1.2552 & & & \\
\hline Buguma & A. germinans & Black & 2.9146 & & & \\
\hline Buguma & L. racemosa & White & 2.557 & & & \\
\hline Buguma & R. racemosa & Red & 1.9722 & \multirow{3}{*}{46.35} & \multirow{3}{*}{23.18} & \multirow{3}{*}{$36.0 \pm 12.8$} \\
\hline Buguma & A. germinans & Black & 1.8935 & & & \\
\hline Buguma & L. racemosa & White & 0.7689 & & & \\
\hline
\end{tabular}

Table 6: Carbon stock estimation of different species of mangroves.

Source: [23].

A part from providing better firewood and charcoal quality, red mangroves purify the environment better than other species of mangroves (i.e. white and black). Purification of the atmosphere will ultimately reduce carbon and other green house gases leading to the reduction in ozone layer depletion and climate change.

\section{Conclusion}

Mangrove wood biomass is a solid fuel and an excellent source of renewable energy, which can be used as an alternative energy to reduce the over dependence on petroleum products that pollutes the environment. Firewood from red mangrove stems has high calorific value after petroleum; therefore it has good burning property. It is mostly utilized in the tropics for cooking, but can be used in the temperate regions and developed countries for heating homes during winter because of its long lasting heating ability and less production of atmospheric pollutants. The use of firewood would produce less carbon foot prints as compared to petroleum that has adverse environmental consequences. Mangrove trees have quick turnover period (15 years) and can easily be replaced during our life time, but for petroleum when it depletes it cannot be replaced in 
a life time because it takes millions of years to form. The utilization of renewable energy is sustainable because future generations can benefit from it a compared to non-renewable resource.

\section{Recommendation}

To advance firewood technology, a biomass energy processing plant can be installed across communities in Africa to accelerate the conversion of firewood and charcoal into liquid, gaseous and electrical energy. Since biomass energy require cutting down of trees a regulatory agency need to be established to monitor patterns of deforestation, and encourage controlled harvesting and aggressive afforestation programs to counter the negative consequences of tree removal such as climate change, soil degradation and habitat and biodiversity losses. Gradual increase in use of renewable energy can lead to the drastic reduction in the use of fossil fuel, which in the long run will be a win-win for the environment. The mangroves of the Niger Delta are excellent sequesters of pollutants which had reduced the quantity of pollutants in the skies of Africa.

\section{References}

1. Giri C, Zhu Z, Tieszen LL, Singh A, Gillette S, Kelmelis JA (2008) Mangrove forest distributions and dynamics (1975-2005) of the tsunami-affected region of Asia. Journal of Biogeography 35(3): 519-528.

2. Numbere AO (2018a) The impact of oil and gas exploration: Invasive nypa palm species and urbanization on mangroves in the Niger River Delta, Nigeria. In Threats to Mangrove Forests, Springer, Cham. pp. 247266.

3. Krauss KW, Osland MJ (2020) Tropical cyclones and the organization of mangrove forests: A Review. Annals of Botany 125(2): 213-234.

4. Fickert $T$ (2018) Better Resilient than resistant-regeneration dynamics of storm-disturbed mangrove forests on the Bay Island of Guanaja (Honduras) during the First Two Decades after Hurricane Mitch (October 1998). Diversity 10(1): 8.

5. Mitra A (2020) Mangroves: A shield against Storms and Wave Actions. In Mangrove Forests in India. Springer, Cham, pp. 33-57.

6. Ozturk M, Saba N, Altay V, Iqbal R, Hakeem KR, et al. (2017) Biomass and bioenergy: An overview of the development potential in Turkey and Malaysia. Renewable and Sustainable Energy Reviews 79: 1285-1302.

7. Senelwa K, Sims RE (1999) Opportunities for small scale biomasselectricity systems in Kenya. Biomass and Bioenergy 17(3): 239-255.

8. Mc Gowan F (1991) Controlling the greenhouse effect- the role of renewable. Energy Policy 111-118.

9. Hall DO, Rosillo-Calle F, De Groot P (1992) Biomass energy-lessons from case studies in developing countries. Energy Prospects, pp. 62-73.

10. Hayes D (1980) Solar possibilities. In: Renewable Energy Prospects, Wilfrid B, Walther M, William H, Harrison B (Eds.), Pergamon Press New York, USA.

11. Akinbami J (2001) Renewable energy resources and technology in Nigeria: Present situation, future prospects and policy framework. Mitigation and Adaptation Strategies for Global Change 6: 155-181.
12. Numbere AO (2018b) Mangrove Species Distribution and Composition, Adaptive Strategies and Ecosystem Services in the Niger River Delta, Nigeria. Mangrove Ecosystem Ecology and Function, p. 17.

13. UNEP (2006) Marine and coastal ecosystems and human wellbeing: A synthesis report based on the findings of the Millennium Ecosystem Assessment. UNEP, p. 76.

14. Numbere AO (2014) Impact of hydrocarbon pollution on the mangrove ecosystem of the Niger River Delta, Nigeria. Doctoral dissertation, Dissertation, Saint Louis University, Missouri, USA.

15. Hamilton LS, Snedaker SC (1984) Handbook for mangrove area management. East-West Environment and Policy Institute, Honolulu, Hawaii, USA.

16. Numbere AO (2019) Perception of Mangrove forest protection and utilization amongst residents in some coastal com-munities in the Niger Delta, Nigeria. Curr Trends Forest Res 3(1039): 2638-3013.

17. Numbere AO (2018c) Mangrove Species Distribution and Composition, Adaptive Strategies and Ecosystem Services in the Niger River Delta, Nigeria. Mangrove Ecosystem Ecology and Function, p.17.

18. A topic on wood density (2018) http://www.kominkowe.info/en/ wartosc-opalowa/.

19. Sathe SS, Lavate RA, Bhosale LJ (2013) Mangrove as source of energy for Rural development with special reference to Ratnagiri and Sindhudarg district (MS) India. Bioscience Discovery 4(2): 198-201.

20. Eze CI (2004) Alternative energy resources (with comments on Nigeria's position). Macmillan Nigeria Publishers Limited, Yaba Lagos, Yaba.

21. Donato DC, Kauffman JB, Murdiyarso D, Kurnianto S, Stidham M, et al. (2011) Mangroves among the most carbon-rich forests in the tropics. Nature geoscience 4(5): 293-297.

22. John A van Aardenne, Carmichael GR, Levy II H, Streets D, Hordijk L (1999) Anthropogenic NOx emissions in Asia in the period 19902020. Atmospheric Environment 33(4): 633-646.

23. Numbere AO, Camilo GR (2018) Structural characteristics, aboveground biomass and productivity of mangrove forest situated in areas with different levels of pollution in the Niger Delta, Nigeria. Afr J of Ecol 56(4): 917-927.

24. Chave J, Andalo C, Brown S, Cairns, MA, Chamber JQ, et al. (2005) Tree allometry and improved estimation of carbon stocks and balance in tropical forests. Oecologia 145: 87-99.

25. Chave J, Coomes D, Jansen S, Lewis SL, Swenson NG, et al. (2009) Towards a worldwide wood economics spectrum. Ecology Letters 12(4): 351-366.

26. Zanne AE, Lopez-Gonzalez G, Coomes DA, Ilic J, Jansen S, et al. (2009) Data from: towards a worldwide wood economics spectrum. Dryad Digital Repository.

27. FAO (1994) Mangrove forest management guidelines. FAO Forestry Paper No. 117.

28. Sitoe AA, Mandlate LJC, Guedes BS (2014) Biomass and carbon stocks of Sofala bay mangrove forests. Forests 5(8): 1967-1981. 